\title{
CURRENT
}

Jurnal Kajian Akuntansi dan Bisnis Terkini

https://current.ejournal.unri.ac.id

\section{DETERMINAN AKUNTABILITAS KINERJA INSTANSI PEMERINTAH : STUDI PADA PEMERINTAH KOTA PEKANBARU}

\author{
Sri Haryani ${ }^{*}$, Julita Julita ${ }^{2}$ \\ ${ }^{12}$ Program Studi Akuntansi, Fakultas Ekonomi dan Bisnis, Universitas Riau, Pekanbaru \\ *Email: yanisrihayani4@gmail.com
}

\section{Keywords \\ Budget Goal Clarity, Competence, Internal Control, Obedience to the Law, Performance Accountability}

\section{Article information}

Received: 2020-07-25

Accepted:

2021-03-26

Available Online:

2021-04-02

\begin{abstract}
The problem in this study is about the performance accountability value obtained by OPD of Pekanbaru City Which is still low. This research was conducted at the OPD of Pekanbaru City with the aim to know the influence of budget goal clarity, government official competence, internal control, and obedience to the laws and regulations on the performance accountability of government agencies. The population in this study is 43 OPD's Pekanbaru City. In this study, the sample used was 32 OPD with a total 96 respondents using purposive sampling method. This study uses primary data by distribusing questionnaires. The analytical method used in this study is multiple linear regression analysis. The analycal tool used in this study is software SPSS version 25.0. The results of this study indicate date budget goal clarity influences on the performance accountability of government agencies, government official competence influences on the performance accountability of government agencies, internal control influences on the performance accountability of government agencies, obedience to the laws and regulationsinfluenceson the performance accountability of government agencies.
\end{abstract}

\section{PENDAHULUAN}

Perkembangan akuntansi sektor publik, khususnya di Indonesia semakin pesat dengan adanya era reformasi dalam pelaksanaan kebijakan pemerintah otonomi daerah dan desentralisasi fiskal yang menitikberatkan pada pemerintah daerah. Kinerja pemerintahan akhir-akhir ini menjadi sorotan publik karena masyarakat mulai mempertanyakan nilai yang mereka peroleh atas pelayanan pemerintah itu sendiri. Pemerintah dituntut untuk bertanggung jawab atas lembaga-lembaga publik baik pusat maupun daerah, yang menyebabkan seluruh instansi pemerintah menyusun perencanaan strategi yaitu melakukan pengukuran kinerja dan melaporkannya.

Semakin meningkatnya tuntutan masyarakat terhadap penyelenggaraan pemerintahan yang baik (good governance) telah mendorong pengembangan dan penerapan sistem 
pertanggungjawaban yang jelas dan efektif. Salah satu upaya dalam mewujudkan pemerintahan yang baik yaitu penerapan akuntabilitas kinerja instansi pemerintah pada pengelolaan pemerintah pusat maupun daerah yang diyakini mampu mengubah kondisi pemerintahan yang masih kurang dalam memberikan pelayanan publik secara baik dan bersih dari praktik korupsi, kolusi, dan nepotisme.

Akuntabilitas kinerja instansi pemerintah adalah perwujudan kewajiban suatu instansi pemerintah untuk mempertanggungjawabkan keberhasilan dan kegagalan pelaksanaan misi organisasi dalam mencapai sasaran dan tujuan organisasi. Hal ini juga sejalan dengan "Peraturan Presiden Republik Indonesia Nomor 29 Tahun 2014 tentang Sistem Akuntabilitas Kinerja Instansi Pemerintah disebutkan bahwa akuntabilitas kinerja adalah perwujudan kewajiban suatu instansi pemerintah untuk mempertanggungjawabkan keberhasilan atau kegagalan pelaksanaan program dan kegiatan yang telah diamanatkan para pemangku kepentingan dalam rangka mencapai misi organisasi secara terukur dengan sasaran dan target yang telah di tetapkan melalui laporan kinerja instansi yang disusun secara periodik".

Berdasarkan Laporan Hasil Evaluasi Pemeriksaan (LHE AKIP) oleh Pemerintah Kota Pekanbaru yang mana tingkat akuntabilitas sebagian organisasi perangkat daerah (OPD) masih tergolong rendah. Pada tahun 2018 ini, Pekanbaru hanya mampu meraih prediket CC dengan nilai 54,68 saja. Penilaian SAKIP pada tahun 2018 lalu menilai performa kinerja tahun 2017 dimana pemerintah Kota Pekanbaru mendapat nilai C. Pekanbaru kalah dari Kabupaten Kepulauan Meranti dan Kuantan Singingi yang bisa melompat dari D ke B dalam waktu setahun. OPD harus cerdas mengimplementasikan anggaran dengan program pemerintah Kota Pekanbaru (https://pekanbaru.tribunnews.com).

Dari tahun 2016 sampai 2018 nilai SAKIP di Pemerintah Kota Pekanbaru mengalami kenaikan tetapi masih belum maksimal. Untuk mencapai terwujudnya suatu akuntabilitas kinerja yang baik ada beberapa faktor yang mempengaruhi antara lain kejelasan sasaran anggaran, kompetensi aparatur pemerintah pengendalian intern dan ketaatan pada peraturan perundangan.

Kejelasan sasaran anggaran merupakan "sejauh mana tujuan anggaran ditetapkan secara jelas dan spesifik dengan tujuan agar anggaran tersebut dapat dipahami oleh pihak yang bertanggung jawab atas pencapaian sasaran anggaran tersebut" (Bastian, 2010). Dalam penelitian oleh Yulianti (2014) menyatakan kejelasan sasaran anggaran berpengaruh terhadap akuntabilitas kinerja instansi pemerintah. Begitu juga dengan penelitian Wahyuni (2014) menyatakan kejelasan sasaran anggaran berpengaruh terhadap akuntabilitas kinerja instansi pemerintah. Namun demikian, terdapat ketidakkonsistenan hasil penelitian. Dalam penelitian 
yang dilakukan oleh Lestari (2015) yang menyatakan kejelasan sasaran anggaran tidak berpengaruh terhadap akuntabilitas kinerja instansi pemerintah.

Faktor selanjutnya adalah kompetensi aparatur pemerintah. Berdasarkan "Badan Kepegawaian Negara No. 46A Tahun 2003, kompetensi aparatur pemerintah adalah kemampuan dan karakteristik yang di miliki oleh seorang pegawai negeri sipil berupa pengetahuan, keterampilan dan perilaku yang di perlukan dalam pelaksanaan tugas jabatannya, sehingga pegawai negeri sipil tersebut dapat melakukan tugasnya secara profesional, efektif dan efisien". Jika tercapainya peningkatan pada kompetensi aparatur pemerintah maka akan berdampak pada akuntabilitas kinerja instansi pemerintah (Biworotomo, 2016). Penelitian yang dilakukan Putri (2015) menunjukkan bahwa kompetensi aparatur pemerintah daerah berpengaruh terhadap akuntabilitas kinerja instansi pemerintah. Penelitian yang dilakukan Mubaraq (2017) menyatakan kompetensi aparatur pemerintah berpengaruh signifikan terhadap akuntabilitas kinerja instansi pemerintah. Hasil penelitian ini bertolak belakang dengan penelitian Rofika, et al. (2014) yang menyatakan kompetensi aparatur pemerintah daerah tidak berpengaruh terhadap akuntabilitas kinerja instansi pemerintah.

Faktor selanjtnya adalah pengendalian intern. Pengendalian intrn adalah" suatu cara untuk mengarahkan, mengawasi dan mengukur sumber daya suatu organisasi serta berperan penting dalam pencegahan dan pendeteksian penggelapan/fraud" (Rahman,2012). Berdasarkan "PP No. 60 Tahun 2008 Sistem Pengendalian Intern adalah proses yang integral pada tindakan dan kegiatan yang dilakukan secara terus menerus oleh pimpinan dan seluruh pegawai untuk memberikan keyakinan yang memadai atas tercapainya tujuan organisasi melalui kegiatan yang efektif dan efisien keandalan pelaporan keuangan pengamanan aset Negara dan ketaatan terhadap peraturan perundang-undangan”. Dalam penelitian yang dilakukan oleh Perwira (2016) juga melakukan penelitian yang berpendapat bahwa pengendalian intern juga berpengaruh positif terhadap akuntabilitas kinerja instansi pemerintah. Hasil penelitian ini bertolak belakang dengan penelitian Wahyuni (2014) yang menyatakan pengendalian intern tidak berpengaruh terhadap akuntabilitas kinerja instansi pemerintah. Perbedaan penelitian sebelumnya dengan penelitian ini terletak pada wilayah yang digunakan dan juga tahun penelitian.

Menurut Bastian (2010:33), ketaatan pada peraturan perundangan adalah kepatuhan seseorang dalam menaati peraturan yang telah dibentuk oleh lembaga Negara atau pejabat yang berwenang dan mempunyai kekuatan mengikat agar dapat mengatur dan menertibkan setiap kehidupan berbangsa dan bernegara. Penelitian yang dilakukan oleh Mubaraq (2017) 
menyatakan bahwa ketaatan peraturan perundang-undangan berpengaruh terhadap akuntabilitas kinerja instansi pemerintah. Perbedaan pada penelitian ini dengan penelitian Husnul Mubaraq adalah pada wilayah penelitian yaitu penelitian Husnul Mubaraq (2017) wilayah yang digunakan di Kota Bukittinggi sedangkan penelitian ini Kota Pekanbaru.

Penelitian ini bertujuan untuk meneliti pengaruh kejelasan sasaran anggaran, kompetensi, pengendalian intern, dan ketaatan pada peraturan terhadap kinerja instansi pemerintah pada pemerintah kota Pekanbaru.Penelitian mengenai kinerja instansi pemerintah masih menarik untuk dilakukan karena masih banyaknya permasalahan mengenai akuntabilitas pada pemerintahan. Penelitian berbeda dengan penelitian sebelumnya (Septiyani,2020) yaitu menggunakan kejelasan sasaran sebagai salah satu faktor yang memepengaruhi akuntabilitas kinerja instansi pemerintah. Penelitian ini diharapkan memeliki kontribusi pada pemerintah dalam meningkatkan akuntabilitas kinerja instansi pemerintah.

\section{PENGEMBANGAN HIPOTESIS}

\section{Pengaruh Kejelasan Sasaran Anggaran Terhadap Akuntabilitas Kinerja Instansi Pemerintah}

Kejelasan sasaran anggaran merupakan sejauh mana tujuan anggaran ditetapkan secara jelas dan spesifik dengan tujuan agar anggaran tersebut dapat dipahami oleh pihak yang bertanggungjawab atas pencapaian sasaran anggaran tersebut. Dengan adanya sasaran anggaran yang jelas, aparat pelaksana anggaran juga akan terbantu dalam pereleasiannya, secara tidak langsung ini akan mempengaruhi terhadap kinerja aparat. Terkait dengan hal ini, kinerja aparat dapat dipengaruhi oleh kejelasan sasaran anggaran sehingga ikut berdampak pada kinerja anggaran dan akuntabilitas kinerja instansi pemerintah (Ramandei,2010).

Menurut penelitian Setiawan (2013) menyatakan bahwa kejelasan sasaran anggaran memiliki pengaruh positif terhadap Akuntabilitas kinerja instansi pemerintah Kabupaten Pelalawan. Begitu penelitian dari Wahyuni (2014) menunjukkan bahwa variabel kejelasan sasaran anggaran berpengaruh terhadap akuntabilitas kinerja instansi pemerintah Kabupaten Rokan Hulu. Berdasarkan uraian di atas, maka dapat dirumuskan hipotesis:

\section{$\mathrm{H}_{1}$ : Kejelasan sasaran anggaran berpengaruh terhadap akuntabilitas kinerja instansi pemerintah.}

\section{Pengaruh Kompetensi Aparatur Pemerintah Terhadap Akuntabilitas Kinerja Instansi Pemerintah}

Menurut Wibowo (2010:324) kompetensi adalah suatu kemampuan untuk 
melaksanakan atau melakukan suatu pekerjaan atau tugas yang dilandasi atas keterampilan dan pengetahuan, serta didukung oleh sikap kerja yang dituntut oleh pekerjaan tersebut. Ini berarti sumber daya yang digunakan harus benar-benar konsisten di bidangnya dalam pelaksanaan akuntabilitas kinerja instansi pemerintah yang efektif, karena kompetensi akan mempengaruhi tingkat akuntabilitas kinerja instansi pemerintah.

Hubungan antara AKIP dengan kompetensi aparatur pemerintah adalah sebagai kualitas aparatur dalam setiap instansi memberikan dampak yang lebih baik terhadap peningkatan kualitas birokrasinya. Untuk peningkatan akuntabilitas kinerja instansi pemerintah daerah (AKIP), perlu adanya pelatihan dan pemahaman lebih mendalam bagi aparatur pemerintah daerah dalam membuat indikator kinerja utama (IKU) yang menjadi dasar untuk evaluasi. Jika tercapainya peningkatan pada kompetensi aparatur pemerintah maka akan berdampak pada akuntabilitas kinerja instansi pemerintah. (Biworotomo, 2016).

Pernyataan ini didukung oleh Septiyani (2020) yang melakukan penelitian pada OPD di Kota Pekanbaru dan Hafiz (2017) yang melakukan penelitian pada Pemerintah Kabupaten Kampar menyimpulkan bahwa variabel kompetensi aparatur pemerintah berpengaruh terhadap akuntabilitas kinerja instansi pemerintah. Oktrianda (2010) juga meneliti pengaruh kompetensi aparatur pemerintah daerah terhadap akuntabilitas kinerja instansi pemerintah di Kota Dumai menyimpulkan bahwa kompetensi aparatur pemerintah daerah memiliki pengaruh yang positif terhadap akuntabilitas kinerja instansi pemerintah. Berdasarkan uraian di atas, maka dapat dirumuskan hipotesis:

\section{$\mathrm{H}_{2}$ : Kompetensi aparatur pemerintah berpengaruh terhadap akuntabilitas kinerja instansi pemerintah.}

\section{Pengaruh Pengendalian Intern Terhadap Akuntabilitas Kinerja Instansi Pemerintah}

Berdasarkan "Peraturan Pemerintah No. 60 Tahun 2008 Sistem Pengendalian Intern adalah proses yang integral pada tindakan dan kegiatan yang dilakukan secara terus menerus oleh pimpinan dan seluruh pegawai untuk memberikan keyakinan yang memadai atas tercapainya tujuan organisasi melalui kegiatan yang efektif dan efisien, keandalan pelaporan keuangan, pengamanan aset negara, dan ketaatan terhadap peraturan perundang-undangan". Di pemerintahan hubungan pengendalian internal dengan akuntabilitas kinerja instansi pemerintah adalah untuk menyelaraskan keandalan laporan akuntabilitas kinerja, efektivitas dan efisiensi operasi serta ketaatan terhadap hukum dan peraturan yang berlaku dalam terciptanya pemerintahan yang berakuntabilitas menjadi tugas tim internal pemerintah daerah dalam hal ini adalah tim pengendali sistem akuntabilitas kinerja instansi pemerintah dan 
pimpinan instansi pemerintah.

Penelitian yang dilakukan Afrina (2015) dan Septiyani (2020) berpendapat bahwa pengendalian intern berpengaruh terhadap akuntabilitas kinerja instansi pemerintah Kota Pekanbaru. Begitu juga Nurhabibah (2018) menyatakan bahwa pengendalian intern berpengaruh positif signifikan terhadap akuntabilitas kinerja instansi pemerintah. Berdasarkan uraian di atas, maka dapat dirumuskan hipotesis:

\section{$\mathrm{H}_{3}$ : Pengendalian intern berpengaruh terhadap akuntabilitas kinerja instansi pemerintah.}

\section{Pengaruh Ketaatan Pada Peraturan Perundangan Terhadap Akuntabilitas Kinerja Instansi Pemerintah}

"Ketaatan pada peraturan perundangan adalah kepatuhan seseorang dalam menaati peraturan yang telah dibentuk oleh lembaga negara atau pejabat yang berwenang dan mempunyai kekuatan mengikat agar dapat mengatur dan menertibkan setiap kehidupan berbangsa dan bernegara" (Bastian, 2010:33). Berdasarkan ketetapan Lembaga Administrasi Negara Tahun 2003, bahwa pelaksanaan akuntabilitas kinerja instansi pemerintah harus berdasarkan suatu sistem yang dapat menjamin penggunaan sumber-sumber daya secara konsisten dengan peraturan perundangan yang berlaku.

Menurut penelitian Mahmud (2013) menyatakan bahwa ketaatan pada peraturan perundangan memiliki pengaruh terhadap akuntabilitas kinerja instansi pemerintah Provinsi Gorontalo. Penelitian Setyawan (2017) menyimpulkan bahawa variabel ketaatan pada peraturan perundangan memiliki pengaruh signifikan terhadap akuntabilitas kinerja instansi pemerintah Kabupaten Pelalawan. Berdasarkan uraian diatas, maka dapat dirumuskan hipotesis:

\section{$\mathrm{H}_{4}$ : Ketaatan Pada Peraturan Perundangan berpengaruh terhadap akuntabilitas kinerja instansi pemerintah.}

\section{METODE PENELITIAN}

\section{Populasi dan Sampel}

Populasi dalam penelitian ini adalah Organisasi Perangkat Daerah (OPD) yang ada di Kota Pekanbaru dengan jumlah Organisasi Perangkat Daerah yaitu 43 organisasi perangkat daerah.

Sampel dalam penelitian menggunakan metode purposive sampling. Kriteria sampel dalam penelitian adalah Oganisasi Perangkat Daerah (OPD) yang memiliki sistem pengendalian internal yang terdiri dari Sekretariat, Inspektorat, Dinas, Badan, Kantor, dan 
Satpol dikarenakan dianggap memiliki fungsi yang lebih kompleks dalam proses perencanaan sampai dengan pengendalian mengenai anggaran yang akan mempengaruhi kinerja aparat pemerintah daerah. Dari 32 OPD Pekanbaru, masing-masing OPD diambil 3 responden dengan kriteria pegawai yang bertanggungjawab terhadap penyusunan laporan keuangan yang berkualitas, sudah menjabat lebih dari satu (1) tahun di OPD, dan dipandang telah memiliki pemahaman terhadap situasi dan kondisi yang ada dalam OPD. Adapun responden dalam penelitian terdiri dari Kepala OPD, Kasubbag Keuangan, dan Kepala/Staff Penyusun AKIP yang merupakan pihak yang terkait langsung dalam perencanaan, pelaksanaan, pelaporan, pertanggungjawaban dan pengawasan keuangan daerah.

\section{Teknik Pengumpulan Data}

Teknik pengumpulan data yang digunakan dalam penelitian ini menggunakan kuesioner yang dibagikan kepada responden secara langsung kemudian diisi sesuai petunjuk.

\section{Definisi Operasional dan Metode Pengukuran Variabel}

Berikut adalah operasionalisasi variabel yang diukur menggunakan Skala Likert dengan skor 5 poin, mulai dari poin 1 sangat tidak setuju sampai poni 5 sangat setuju, yang menghasilkan data ordinal.

\section{Tabel 1}

\section{Instrumen Penelitian}

\begin{tabular}{|c|c|c|c|}
\hline No & Variabel & Indikator & Skala \\
\hline \multirow[t]{5}{*}{1} & Akuntabilitas & 1. Akuntabilitas Kejujuran & Likert \\
\hline & Instansi Pemerintah & 2. Akuntabilitas Hukum & \\
\hline & & 3. Akuntabilitas Proses & \\
\hline & & 4. Akuntabilitas Program & \\
\hline & & 5. Akuntabilitas Kebijaka & \\
\hline \multirow[t]{7}{*}{2} & Kejelasan & 1. Tujuan & Likert \\
\hline & Anggaran & 2. Kinerja & \\
\hline & & 3. Standar & \\
\hline & & 4. Jangka Waktu & \\
\hline & & 5. Sasaran Prioritas & \\
\hline & & 6. Tingkat Kesulitan & \\
\hline & & 7. Koordinasi & \\
\hline \multirow[t]{3}{*}{3.} & Kompetensi & 1. Pengetahuan & Likert \\
\hline & Pemerintah & 2. Keterampilan & \\
\hline & & 3. Sikap & \\
\hline \multirow[t]{5}{*}{4.} & Pengendalian Intern & 1. Lingkungan Pengendalian & Likert \\
\hline & & 2. Penilaian Resiko & \\
\hline & & 3. Kegiatan Pengendalian & \\
\hline & & 4. Informasi dan Komunikasi & \\
\hline & & 5. Pemantauan Pengendalian Internal & \\
\hline \multirow[t]{3}{*}{5.} & Ketaatan Pada & 1. Kepatuhan Terhadap Perundangan & Likert \\
\hline & Peraturan Perundangan & 2. Pengawasan Terhadap Pelaksanaan & \\
\hline & & Tugas Sesuai Dengan Peraturan & \\
\hline
\end{tabular}

Sumber: Data Olahan (2019)

\section{Metode Analisis Data}

Dalam penelitian ini, metode pengujian menggunakan uji analisis linear berganda, uji 
statistik deskriptif, uji kualitas data dan uji asumsi klasik dengan menggunakan alat bantu statistik program SPSS versi 25.0. Model uji analisis linear berganda adalah sebagai berikut: $\mathrm{Y}=\alpha+\beta 1 . \mathrm{X} 1+\beta 2 . \mathrm{X} 2+\beta 3 . \mathrm{X} 3+\beta 4 . \mathrm{X} 4+\beta 5 . \mathrm{X} 5+\mathrm{e}$

Keterangan:

$$
\begin{aligned}
\mathrm{Y} & =\text { Akuntabilitas Kinerja Instansi Pemerintah } \\
\alpha & =\text { Konstanta } \\
\beta 1 & =\text { Koefisien regresi Kejelasan Sasaran Anggaran } \\
\beta 2 & =\text { Koefisien regresi Kompetensi Aparatur Pemerintah } \\
\beta 3 & =\text { Koefisien regresi Pengendalian Intern } \\
\beta 4 & =\text { Koefisien regresi Ketaatan Pada Peraturan Perundangan } \\
\mathrm{X} 1 & =\text { Variabel Kejelasan Sasaran Anggaran } \\
\mathrm{X} 2 & =\text { Variabel Kompetensi Aparatur Pemerintah } \\
\mathrm{X} 3 & =\text { Variabel Pengendalian Intern } \\
\mathrm{X} 4 & =\text { Variabel Ketaatan Pada Peraturan Perundangan } \\
\mathrm{e} & =\text { Eror (kesalahan regresi) }
\end{aligned}
$$

\section{HASIL PENELITIAN DAN PEMBAHASAN}

\section{Tingkat Pengembalian Kuesioner}

Total kuesioner yang disebarkan kepada 32 OPD Kota Pekanbaru berjumlah 96 kuesioner. Dimana setiap organisasi perangkat daerah (OPD) mendapatkan 3 kuesioner yang respondennya terdiri dari Kepala OPD, Kasubag Keuangan, dan Kepala/Staff penyusun AKIP. Dari 96 kuesioner yang disebarkan, ada 12 kuesioner yang tidak kembali karena disebabkan oleh kesibukan pejabat pemerintah daerah. Jadi tingkat pengembalian kuesioner sebesar $87,5 \%$.

\section{Karakteristik Responden}

Karakteristik responden yang berpartisipasi dalam penelitian ini dapat dilihat dari umur, jenis kelamin, masa kerja, dan tingkat pendidikan. Dari hasil penelitian ini, responden yang banyak berpartisipasi berumur 31-40 tahun, berjenis kelamin laki-laki, lama bekerja lebih dari 10 tahun dan pendidikan S1.

\section{Hasil Uji Statistik Deskripstif}

Tabel berikut menampilkan hasil uji statistik deskriptif berdasarkan data yang diperoleh dari pengisian kuesioner oleh responden 


\section{Tabel 2}

\section{Hasil Uji Statistik Deskriptif}

\begin{tabular}{lccccc}
\hline & N & Min & Max & Mean & Std. Deviation \\
\hline Kejelasan Sasaran Anggaran (X1) & 84 & 24 & 35 & 29,68 & 1,983 \\
Kompetensi Aparatur Pemerintah (X2) & 84 & 31 & 47 & 39,10 & 3,389 \\
Pengendalian Intern (X3) & 84 & 43 & 67 & 55,35 & 4,934 \\
Ketaatan Pada Peraturan Perundangan (X4) & 84 & 12 & 20 & 16,65 & 1,704 \\
Akuntabilitas Kinerja Instansi Pemerintah (Y) & 84 & 34 & 55 & 45,46 & 4,370
\end{tabular}

Sumber: Olah data dengan menggunakan SPSS

Berdasarkan pengujian statistik di atas, dapat dilihat dari nilai minimum, maximum, mean dan standar deviasi yang menunjukkan bahwa masing-masing variabel baik independen maupun dependen terdapat responden yang menjawab kuesioner dengan jawaban paling rendah adalah sangat tidak setuju dan jawaban paling tinggi adalah sangat setuju serta memiliki sebaran data tidak terlalu besar karena standar deviasinya lebih kecil dari nilai ratarata.

\section{Hasil Uji Validitas dan ReliabilitasData}

Pengujian validitas dilakukan dengan menggunakanan pearson correlation yaitu membandingkan nilai $r$ hitung dengan $r$ tabel pada taraf signifikan 5\% untuk uji 2 sisi. Jika $r$ hitung $>\mathrm{r}_{\text {tabel }}$ maka item pertanyaan yang digunakan dalam penelitian ini adalah valid. Pada penelitian ini diperoleh nilai $r$ tabel dengan derajat bebas (df) 82 adalah 0,2146. Hasil penelitian yang diperoleh menyatakan bahwa $r_{\text {hitung }}>r_{\text {tabel }}$ Artinya pernyataan dalam penelitian ini valid.

\section{Tabel 3}

\section{Hasil Uji Validitas dan Reliabilitas}

\begin{tabular}{|c|c|c|c|c|c|}
\hline Variabel & $\mathrm{r}_{\text {hitung }}$ & $\mathrm{r}_{\text {tabel }}$ & Keterangan & $\begin{array}{c}\text { Cronbach } \\
\text { Alpha }\end{array}$ & Keterangan \\
\hline $\begin{array}{l}\text { Akuntabilitas Kinerja } \\
\text { Instansi Pemerintah (Y) }\end{array}$ & $0,482-0.748$ & 0,2146 & Valid & 0,836 & Reliabel \\
\hline $\begin{array}{c}\text { Kejelasan Sasaran } \\
\text { Anggaran }(X 1)\end{array}$ & $0,479-0,745$ & 0,2146 & Valid & 0,697 & Reliabel \\
\hline $\begin{array}{l}\text { Kompetensi Aparatur } \\
\text { Pemerintah (X2) }\end{array}$ & $0,498-0,714$ & 0,2146 & Valid & 0,714 & Reliabel \\
\hline Pengendalian Intern (X3) & $0,370-0,851$ & 0,2146 & Valid & 0,786 & Reliabel \\
\hline $\begin{array}{c}\text { Ketaatan pada Peraturan } \\
\text { (X4) }\end{array}$ & $0,700-0,828$ & 0,2146 & Valid & 0,664 & Reliabel \\
\hline
\end{tabular}

Sumber: Olah data dengan menggunakan SPSS

Berdasarkan hasil uji reliabilitas, menunjukkan nilai Cronbath Alpha lebih besar dari 0,60 sehingga dapat disimpulkan indikator atau kuesioner untuk semua variabel dalam penelitian ini dinyatakan reliabel. 


\section{Hasil Uji Normalitas}

Hasil uji normalitas dapat dilihat pada grafik p plot berikut :

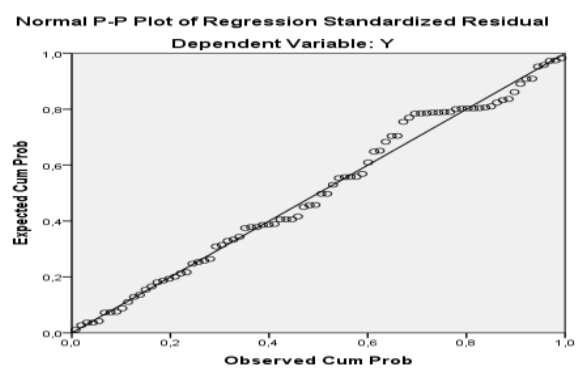

Gambar 1

\section{Hasil Uji Normalitas}

Berdasarkan gambar di atas terlihat data menyebar di sekitar dan mengikuti garis diagonal. Artinya data penelitian berdistribusi secara normal.

\section{Hasil Uji Multikolinearitas}

\section{Tabel 4}

\section{Hasil Uji Multikolinearitas}

Model

Kejelasan sasaran anggaran

Kompetensi aparatur pemerintah

Pengendalian intern

Ketaatan pada peraturan perundangan

Sumber: Olah data dengan menggunakan SPSS

Berdasarkan tabel diatas diketahui nilai variance inflation factor (VIF) $<10$ dan tolerance $>0,10$. Artinya tidak terjadi gejala multikolinearitas dalam model regresi,

\section{Hasil Uji Heteroskedastisitas}

Hasil uji heteroskedastisitas dapat dilihat pada grafik dibawah :

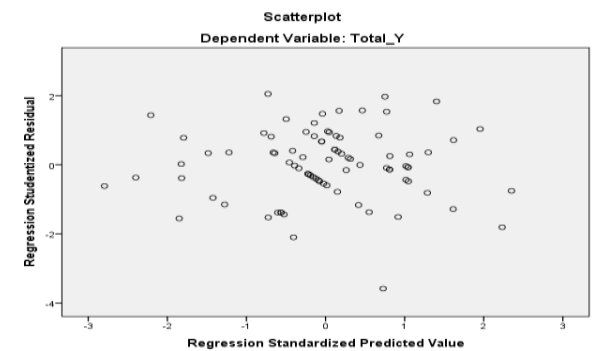

\section{Gambar 2}

\section{Hasil Uji Heteroskedastisitas}

Berdasarkan gambar di atas terlihat titik-titik menyebar secara acak, tidak membentuk suatu pola tertentu yang jelas, serta tersebar di atas dan di bawah angka 0. Artinya tidak terdapat gejala heteroskedastisitas. 


\section{Hasil Uji Analisis Regresi Linear Berganda}

Hasil analisis Linier berganda dapat dilihat pada tabel berikut:

\section{Tabel 3}

Hasil Uji Analisis Regresi Linear Berganda

\begin{tabular}{|c|c|c|c|c|c|c|c|}
\hline & \multirow{2}{*}{ Model } & \multicolumn{2}{|c|}{$\begin{array}{c}\text { Unstandardized } \\
\text { Coefficients }\end{array}$} & \multirow{2}{*}{$\begin{array}{c}\begin{array}{c}\text { Standardized } \\
\text { Coefficients }\end{array} \\
\text { Beta } \\
\end{array}$} & \multirow{2}{*}{$\mathbf{T}$} & \multirow{2}{*}{ Sig. } & \multirow[t]{2}{*}{$\underset{\mathbf{R}^{2}}{\text { Adjusted }}$} \\
\hline & & B & $\begin{array}{l}\text { Std. } \\
\text { Error }\end{array}$ & & & & \\
\hline \multirow[t]{5}{*}{1} & (constant) & $-9,031$ & 5,221 & & $1, \overline{-}$ & 0,088 & \multirow{5}{*}{0,651} \\
\hline & $\begin{array}{l}\text { Kejelasan Sasaran Anggaran } \\
\text { (X1) }\end{array}$ & 0,370 & 0,147 & 0,168 & 2,514 & 0,014 & \\
\hline & $\begin{array}{l}\text { Kompetensi Aparatur } \\
\text { Pemerintah (X2) }\end{array}$ & 0,595 & 0,120 & 0,461 & 4,960 & 0,000 & \\
\hline & Pengendalian Intern (X3) & 0,238 & 0,087 & 0,269 & 2,745 & 0,007 & \\
\hline & $\begin{array}{l}\text { Ketaatan Pada Peraturan } \\
\text { Perundangan (X4) } \\
\text { a. Dependent Variable: Akun }\end{array}$ & $\begin{array}{r}0,424 \\
\text { ilititas K }\end{array}$ & $\begin{array}{l}0,199 \\
\text { rja Insta }\end{array}$ & $\begin{array}{c}0,165 \\
\text { Pemerintah }\end{array}$ & 2,134 & 0,036 & \\
\hline
\end{tabular}

Sumber: Olah data dengan menggunakan SPSS

Dari tabel di atas, diperoleh nilai $\mathrm{R}^{2}$ sebesar 0,651. Artinya adalah sumbangan pengaruh variabel kejelasan sasaran anggaran, kompetensi aparatur pemerintah, pengendalian intern dan ketaatan pada peraturan perundangan terhadap akuntabilitas kinerja instansi pemerintah adalah sebesar $65,1 \%$. Sedangkan sisanya $34,9 \%$ dipengaruhi oleh variabel lain yang tidak dimasukkan dalam penelitian.

Berdasarkan hasil uji $\mathrm{t}$ di atas, bahwa $\mathrm{t}_{\text {hitung }}>\mathrm{t}_{\text {tabel }}$ dan tingkat sig.t $<\alpha 0.05$ sehingga dapat disimpulkan bahwa variabel kejelasan sasaran anggaran, kompetensi aparatur pemerintah, pengendalian intern dan ketaatan pada peraturan perundangan berpengaruh terhadap akuntabilitas kinerja instansi pemerintah.

\section{Pengaruh Kejelasan Sasaran Anggaran Terhadap Akuntabilitas Kinerja Instansi Pemerintah}

Kejelasan sasaran anggaran adalah "sejauh mana tujuan anggaran ditetapkan secara jelas dan spesifik dengan tujuan agar anggaran tersebut dapat dimengerti oleh orang yang bertanggung jawab atas pencapain sasaran tersebut". Untuk melihat pengaruh Kejelasan Sasaran Anggaran terhadap Akuntabilitas Kinerja Instansi Pemerintah (AKIP) pada OPD Kota Pekanbaru.

Berdasarkan uji parsial $t$ pada hipotesis pertama, diperoleh nilai $t_{\text {hitung }}(2,514)>t_{\text {tabel }}$ $(1,990)$ dan sig. $(0,014)<(0,05)$. Ini menunjukkan bahwa $\mathrm{H}_{0}$ ditolak dan $\mathrm{H}_{1}$ diterima. Sehingga hasil penelitian menerima hipotesis pertama yang menyatakan kejelasan sasaran anggaran berpengaruh terhadap akuntabilitas kinerja instansi pemerintah. 
Dalam hal peningkatan akuntabilitas kinerja instansi pemerintah Kota Pekanbaru pada aspek kejelasan sasaran anggaran, Pemerintah Kota Pekanbaru diketahui saat ini masih menunjukkan adanya inefisiensi sebesar 30 persen dalam akuntabilitas kinerja. Hal ini terjadi dikarenakan tidak ada keterkaitan program dengan sasaran. Untuk itu pemerintah Kota Pekanbaru dalam menyusun program-program harus jelas sasaran anggarannya guna mengetahui permasalahan yang akan dihadapi dalam upaya peningkatan akuntabilitas kinerja instansi pemerintah Kota Pekanbaru. Adanya sasaran anggaran yang jelas, maka mempermudah untuk mempertanggungjawabkan keberhasilan atau kegagalan pelaksanaan tugas organisasi dalam rangka untuk mencapai tujuan dan sasaran yang telah ditetapkan sebelumnya. Di dalam penelitian ini memberikan bukti bahwa aparatur pemerintah Kota Pekanbaru dalam menyusun program kinerja dengan sasaran anggarannya telah memahami apa yang dilakukan, telah memahami bagaimana kinerja tersebut diukur, telah memiliki sasaran yang jelas dalam melakukan pekerjaan dan mengetahui sasaran prioritas kinerja jika terdapat lebih dari satu sasaran kinerja yang mempunyai pengaruh terhadap akuntabilitas kinerja instansi pemerintah Kota Pekanbaru.

Hasil penelitian ini mendukung penelitian Setiawan (2013), Wahyuni (2014), Yulianti (2014) dan Anjarwati (2012) yang menyimpulkan bahwa kejelasan sasaran anggaran berpengaruh terhadap akuntabilitas kinerja instansi pemerintah.

\section{Pengaruh Kompetensi Aparatur Pemerintah terhadap Akuntabilitas Kinerja Instansi Pemerintah}

Kompetensi merupakan suatu karakteristik yang mendasari seseorang berkaitan dengan efektivitas kinerja individu dalam pekerjaannya atau karakteristik dasar individu yang memiliki hubungan kausal atau sebagai sebab akibat dengan kriteria yang dijadikan acuan, efektif atau berkinerja prima atau superior di tempat kerja atau pada posisi tertentu.

Berdasarkan uji parsial $t$ pada hipotesis kedua, diperoleh nilai $t_{\text {hitung }}(4,960)>t_{\text {tabel }}$ $(1,990)$ dan sig. $(0,000)<(0,05)$. Ini menunjukkan bahwa $\mathrm{H}_{0}$ ditolak dan $\mathrm{H}_{2}$ diterima. Sehingga hasil penelitian menerima hipotesis kedua yang menyatakan kompetensi aparatur pemerintah berpengaruh terhadap akuntabilitas kinerja instansi pemerintah.

Dalam hal peningkatan akuntabilitas kinerja instansi pemerintah Kota Pekanbaru pada aspek kompetensi aparatur pemerintah, Pemerintah Kota Pekanbaru telah mempersiapkan beberapa pelatihan-pelatihan kepada setiap aparatur Pemerintah Kota Pekanbaru dalam hal berupa keterampilan, pengetahuan dan perilaku atau sikap yang diperlukan dalam pelaksanaan tugas jabatannya. Untuk peningkatan akuntabilitas kinerja instansi pemerintah Kota 
Pekanbaru, perlu adanya pelatihan dan pemahaman lebih mendalam bagi aparatur pemerintah daerah dalam membuat indikator kinerja utama yang menjadi dasar untuk evaluasi. Di dalam penelitian ini memberikan bukti bahwa penempatan aparatur pemerintah sesuai dengan latar belakang pendidikan, tingkat kualitas aparatur pemerintah sudah sesuai dengan tuntutan dan kebutuhan organisasi, dan kemampuan aparatur pemerintah untuk melaksanakan tugas-tugas baru yang mempunyai pengaruh positif terhadap akuntabilitas kinerja instansi pemerintah Kota Pekanbaru.

Penelitian ini sejalan dengan penelitian yang dilakukan oleh Septiani et al (2020), Zirman (2010) dan Hafiz (2017) menyimpulkan bahwa variabel kompetensi aparatur pemerintah berpengaruh signifikan terhadap akuntabilitas kinerja instansi pemerintah.

\section{Pengaruh Pengendalian Intern terhadap Akuntabilitas Kinerja Instansi Pemerintah}

Sistem Pengendalian Intern adalah proses yang integral pada tindakan dan kegiatan yang dilakukan secara terus menerus oleh pimpinan dan seluruh pegawai untuk memberikan keyakinan yang memadai atas tercapainya tujuan organisasi melalui kegiatan yang efektif dan efisien, keandalan pelaporan keuangan, pengamanan aset negara, dan ketaatan terhadap peraturan perundang-undangan.

Berdasarkan uji parsial t pada hipotesis ketiga, diperoleh nilai $t_{\text {hitung }}(2,745)>t_{\text {tabel }}$ $(1,990)$ dan sig. $(0,007)<(0,05)$. Ini menunjukkan bahwa $\mathrm{H}_{0}$ ditolak dan $\mathrm{H}_{3}$ diterima. Sehingga hasil penelitian menerima hipotesis ketiga yang menyatakan pengendalian intern berpengaruh terhadap akuntabilitas kinerja instansi pemerintah.

Dalam hal peningkatan akuntabilitas kinerja instansi Pemerintah Kota Pekanbaru pada aspek pengendalian intern, pemerintah Kota Pekanbaru telah mulai menerapkan pengendalian internal yang efektif dan memadai untuk menekan terjadinya kesalahan dan penyelewengan dalam menjalankan aktivitas organisasi. Diharapkan pimpinan instansi Pemerintah Kota Pekanbaru mengetahui secara jelas mengenai gambaran kinerja organisasi perangkat daerahnya sehingga dapat berkoordinasi dengan tim pengendali sistem akuntabilitas kinerja instansi pemerintah untuk menyelenggarakan akuntabilitas kinerja dengan indikator yang telah ditentukan. Di dalam penelitian ini memberikan bukti bahwa adanya penegakan integritas dan nilai etika, adanya pendelegasian wewenang dan tanggung jawab yang tepat, adanya review atas kinerja instansi pemerintah yang bersangkutan, telah melakukan penilaian resiko dan adanya evaluasi terpisah yang mempengaruhi akuntabilitas kinerja instansi Pemerintah Kota Pekanbaru. Penelitian ini sejalan dengan penelitian yang dilakukan Silalahi (2017) dan Nurhabibah (2018) menyatakan bahwa pengendalian intern berpengaruh terhadap 
akuntabilitas kinerja instansi pemerintah.

\section{Pengaruh Ketaatan Pada Peraturan Perundangan terhadap Akuntabilitas Kinerja Instansi Pemerintah}

Ketaatan pada peraturan perundangan adalah suatu bentuk kepatuhan pada aturanaturan yang telah dibuat oleh lembaga negara yang berwenang untuk dipatuhi oleh seluruh warga negara yang berskala nasional.

Berdasarkan uji parsial t pada hipotesis keempat, diperoleh nilai $t_{\text {hitung }}(2,134)>t_{\text {tabel }}$ $(1,990)$ dan sig. $(0,036)<(0,05)$. Ini menunjukkan bahwa $\mathrm{H}_{0}$ ditolak dan $\mathrm{H}_{4}$ diterima. Sehingga hasil penelitian menerima hipotesis keempat yang menyatakan ketaatan pada peraturan perundangan berpengaruh terhadap akuntabilitas kinerja instansi pemerintah.

Dalam hal peningkatan akuntabilitas kinerja instansi pemerintah Kota Pekanbaru pada aspek ketataan pada peraturan perundangan, aparatur pemerintah daerah Kota Pekanbaru dalam menjalankan suatu pekerjaannya haruslah disiplin dan bisa bekerja mengikuti standar. Artinya dalam menjalankan tugas dan kewajiban sesuai dengan peraturan yang berlaku agar tercapai pemerintahan yang berakuntabilitas. Ketaatan pada peraturan perundangan akan mendorong kelancaran program-program yang buat oleh pemerintah Kota Pekanbaru sehingga tercapainya sasaran atau tujuan yang dikehendaki. Di dalam penelitian ini memberikan bukti bahwa dalam pelaksanaan tugas pimpinan dan bawahan telah menaati peraturan perundangan yang berlaku, dan pengawasan terhadap pelaksanaan telah sesuai dengan peraturan yang berlaku yang mempengaruhi akuntabilitas kinerja instansi pemerintah.

Penelitian ini sejalan dengan Septiyani (2020) dan Zirman., et al (2010) yang menunjukkan bahwa pengaruh ketaatan pada peraturan perundangan memiliki pengaruh positif terhadap akuntabilitas kinerja instansi pemerintah.

\section{SIMPULAN}

Hasil dari penelitian ini dapat disimpulkan bahwa kejelasan sasaran anggaran, kompetensi aparatur pemerintah, pengendalian intern, dan ketaatan pada peraturan perundangan berpengaruh terhadap akuntabilitas kinerja instansi pemerintah di OPD Kota Pekanbaru.

Keterbatasan dalam penelitian ini yaitu sulit menyebarkan dan mengumpulkan data kuesioner dikarenakan adanya pandemi COVID-19, tidak dilakukannya metode wawancara dalam penelitian mengingat kesibukan dan jauhnya responden, dan data penelitian hanya dilakukan pada pernyataan yang sifatnya tertutup. Akibatnya adanya keterbatasan tersebut peneliti tidak bisa mengendalikan jawaban responden, peneliti tidak mendapat argumen secara 
langsung dan detail dari responden secara keseluruhan.

Penelitian ini memiliki kontribusi pada pemerintah kota Pekanbaru bahwa dalam meningkatkan akuntabilitas kinerja instansi pemrintah harus memperhatikan kejelasan sasaran anggaran, serta diperlukan pelatihan dalam peningkatan kompetensi aparatur sehingga anggaran dapat dipertanggungjawabkan. Kepatuhan atas peraturan juga diperlukan dalam peningkatan akuntabilitas.

Selain memiliki kontribusi pada pemerintahan penelitian ini juga memiliki kontribusi pada ilmu pengetahuan terutama pada akuntansi pemerintahan. Penelitian ini juga dapat menjadi referensi pada penelitian selanjutnya.

\section{REFERENSI}

Afrina, D. (2015). Pengaruh Penerapan Sistem Akuntabilitas Pemerintah Daerah, Pengendalian Intern dan Sistem Pelaporan Terhadap Akuntabilitas Kinerja Instansi Pemerintah (Studi Persepsian Pada Satuan Kerja Perangkat Daerah Kota Pekanbaru). Jurnal Online. Vol.2 No.2. Hal 1-15.

Anjarwati, M. (2012). Pengaruh Kejelasan Sasaran Anggaran, Pengendalian Akuntansi, dan Sistem Pelaporan Terhadap Akuntabilitas Kinerja Instansi Pemerintah. Jurnal Analisis Keuangan. Vol. 1 No. 2.

Bastian, I. (2010). Akuntansi Sektor Publik: Satuan Pengantar. Jakarta: Erlangga.

Fahrianta, R. W \& Ghozali, I. (2002). Pengaruh Tidak Langsung Sistem Penganggaran Terhadap Kinerja Manajerial: Motivasi Sebagai Intervening. Jurnal Riset Akuntansi, Manajemen dan Ekonomi. Vol 2 (1). Februari: 77-113.

Hafiz, M. (2017). Pengaruh Kompetensi Aparatur Pemerintah, Ketaatan Pada Peraturan Perundangan dan Kejelasan Sasaran Anggaran Terhadap Akuntabilitas Kinerja Instansi Pemerintah Dengan Komitmen Organisasi dan Kinerja Manajerial Sebagai Variabel Moderating (Studi Empiris Pada Satuan Kerja Perangkat Daerah Kabupaten Kampar). Jurnal Ekonomi. Vol.4 No.1 Februari. Hal. 528-542.

Herawaty, N. (2011). Pengaruh Kejelasan Sasaran Anggaran, Pengendalian Akuntansi, dan Sistem Pelaporan Terhadap Akuntabilitas Kinerja Instansi Pemerintah Daerah Kota Jambi. Jurnal Penelitian. Universitas Jambi Seri Humoniora. Vol. 13 No. 2 JuliDesember. Hal. 31-36.

Lembaga Administrasi Negara. (2003). Pedoman Penyusunan Pelaporan Akuntabilitas Kinerja Instansi Pemerintah.

Pamungkas, B. (2012). Pengaruh Penerapan Akuntansi Publik dan Kualitas Peraturan Perundangan Terhadap Kualitas Laporan Keuangan dan Akuntabilitas Kinerja Instansi Pemerintah. Jurnal Ilmiah Rangga Gading. Vol. 12 No.1, (April) 2012:1-10.

Perwirasari, F. B. P. (2016). Faktor-faktor yang Mempengaruhi Akuntabilitas Kinerja Instansi Pemerintah (AKIP). Skripsi. Universitas Negeri Semarang. 
Sekretariat Negara. (2008). Peraturan Pemerintah No. 60 Tahun 2008 Tentang Sistem Pengendalian Intern.

Sekretariat Negara. (2014). Peraturan Presiden Nomor 29 Tahun 2014 Tentang Sistem Akuntabilitas Kinerja Instansi Pemerintah.

Septiyani, G., Taufik, T., \& Julita, J. (2020). Akuntabilitas Kinerja Instansi Pemerintah : Apakah Dipengaruhi Kompetensi Aparatur, Tekhnologi Informasi, Pengendalian Akuntansi, Dan Sistem Pelaporan?. CURRENT: Jurnal Kajian Akuntansi Dan Bisnis Terkini, 1(2), 183-200. https://doi.org/10.31258/jc.1.2.184-201

Setiawan, E. (2013). Pengaruh Kejelasan Sasaran Anggaran, PengendalianAkuntansi, Dan Sistem Pelaporan Terhadap Akuntabilitas Kinerja Instansi Pemerintah (Studi Kabupaten Pelalawan). Jurnal Online. Vol.1 No.1. Universitas Riau.

Undang-Undang RI Nomor 22 Tahun 1999 Tentang Pemerintah Daerah.

Wahid, I. (2016). Pengaruh Kejelasan Sasaran Anggaran, Pengendalian Akuntansi, Kompetensi Aparatur Pemerintah, Sistem Pelaporan, dan Ketaatan terhadap Peraturan Perundangan Terhadap Akuntabilitas Kinerja Instansi Pemerintah (Studi pada SKPD Kabupaten Agam). Jurnal Online. Vol.3 No.1, (Februari), Hal. 2457-2471.

Wahyuni. (2014). Pengaruh Kejelasan Sasaran Anggaran, Pengendalian Akuntansi, dan Sistem Pelaporan terhadap Akuntabilitas Kinerja Instansi Pemerintah (Studi pada SKPD Kabupaten Rokan Hulu). Jurnal Online. Vol.1 No.1. Universitas Riau.

Yulianti, R. (2014). Pengaruh Kejelasan Sasaran Anggaran, Kesulitan Sasaran Anggaran, Pengendalian Akuntansi dan Sistem Pelaporan Terhadap Akuntabilitas Kinerja Instansi Pemerintah (Studi pada SKPD Kabupaten Pelalawan). Jurnal Online. Universitas Riau. Vol.1 No. 2. Universitas Riau.

Zirman., Darlis, E.,\& Rozi. M (2010). Pengaruh Kompetensi Aparatur Pemerintahan Daerah, Penerapan Akuntabilitas Keuangan, Motivasi Kerja, dan Ketaatan Pada Peraturan Perundangan Terhadap Akuntabilitas Kinerja Instansi Pemerintah. Jurnal Ekonomi. Vol.18 No.1, (Maret) 2010. Hal. 1-12. Universitas Riau.

Zulfiandri, A.(2017). Faktor-Faktor yang Mempengaruhi Akuntabilitas Kinerja Instansi Pemerintah (Studi empiris pada OPD di Pemerintah Provinsi Banten). Jurnal Riset Akuntansi. Vol 2 (1). Hal 102-125.

$\underline{\text { www.pekanbaru.tribunnews.com }}$

www.pekanbaru.bpk.go.id 